\title{
Preface: Marianne's Hands
}

The hands of Jeanne-Marie, the hands of Marianne, the hands of women revolutionaries, and the hands of knitters: we unite them deliberately here, these hands of the simple working-class people who rebelled during the French Revolution and those described by the famous poet almost a century later in one of the most beautiful poems about French women revolutionaries. "Dark hands, pale hands" — but are these hands so different, the hands of the woman revolutionary of 1871 and those of 1793 , these hands that "sing the Marseillaise" and those of the idle noblewoman? Rather than shading their pale skin from the sun under the shadows of bronze rifles, Marianne's hands would cry to the president of the Convention: "Beneath these delicate hands have glided the barrels of those bronze entities-those mouths of fire that could make even a king hear thunder in his ear-the augur of change and all destinies!"1

And the bloody Revolution, which at long last succeeded in solidifying the political organization of French society: wasn't its memory illuminated primarily by the "sun's love-provoking light?" - to the displeasure of all the tortured spirits that frequent hate-gatherings and would much rather define it according to the number of decapitated heads and drops of blood spilled than try to understand what values the Revolution brought to light? "Love for oneself [is] love for others, " wrote one historian on the revolutionary mentality. ${ }^{2}$

Marianne's hands were tender upon the forehead of a child, a spouse, or a lover-or raised before her face to fend off a violent husband's blows.

1. Speech by Hérault de Séchelles, 1o August 1793, to the "heroines of the fifth and sixth of October [1789]."

2. Michel Vovelle, La Mentalité révolutionnaire: Société et mentalités sous la Révolution française (Paris: Messidor, 1985). 
They were damaged, "dark like yesterday's breast," by the cold water of the Seine where laundrywomen washed clothes, by the pricks of a needle if she worked in a tailor's shop, or by the spinning wheel if she worked in a mill. They polished metal or crafted fans, pearls, feathers, and other frippery. They sought provisions to feed her family. And they could shock, toowhen they signed or marked a cross at the bottom of a petition, when their fingers followed the lines of a Declaration of Rights or of Robespierre's last speech, when they rose to beg for speech in a revolutionary assembly, when they strove feverishly to affix linen bandages upon the wounds of soldiers fighting on the Republican front line. Or, when they tugged upon a counterrevolutionary's uniform and spread to deliver a stinging slap to his cheek, when they carried their miserable rations of bread under the deputies' noses, only to transform into defiant fists a few minutes later. And, of course, when they knitted, in the tribunes of the National Assembly or before the guillotine.

This book does not describe some famous woman or the universal condition of Woman herself but the common women-the ones who didn't leave their names, the ones who shared in the quest for subsistence, and the ones who worked to earn a bare living, while still finding time every night to take their places in the tribunes of the National Assembly.

We hear of these women from time to time in general works on the Revolution. But even then-at the turn of a phrase, lost within a paragraph - they appear only briefly. Among which passages will they disappear next? What will become of these women when the revolutionary historians no longer cast them the slightest regard? From the moment that women were first granted citizenship, lengthy analyses and even complete chapters have focused on women's liberation, but these remain only parentheses disconnected from a general history. Women are presented apart from the Revolution or beside it; they are not included in the revolutionary process, conceptualized as it is without reference to their involvement. And once we do start to become more particularly interested in the women of the Revolution, it is a Revolution that, despite its richness and complexity, exists only as a backdrop. Women do not seem attached to it in any way-rather, they seem to transcend the social classes and political groups. Although women have become subjects worthy of historical interest, they are denied status as active subjects of Revolutionary history and their actions play more importance in the history of women than in the history of the Revolution. It is as if women constructed their stories alongside the "big story," which remains masculine and in which they are merely the eternal victims. 
Yet the merging of the history of women and the history of the Revolution is possible, so long as we remain attentive to the pitfalls of anachronism. We must refrain from plastering our own historical and intellectual heritage over the archives without taking into account Revolutionary thought, the population, and the social and political contexts of the period. We must not neglect the occasion to point out the frequent willingness to inferiorize women in the sexual, social, economic, and political spheres during the Revolution, although we acknowledge that women were only one of many aspects that formed society and history. To know that women were present in the course of a certain episode, that they did or did not share a certain attitude of the revolutionary mentality-these statements have no fundamental importance unless they illuminate the specific contexts and gender relations of women during the revolutionary movement. Studying women during the Revolution allows us to enrich our comprehension of the revolutionary phenomenon, to put in relief the parts that up till now have rarely been taken into account. The last stipulation is that we must resist drawing the separation between a story that would view ordinary women (and men) only through the distorted prism of their ways of living and of being and their passions, and another that would study the ideas and concepts that belonged to only a few so-called enlightened men at the time. The history of ideas - of the production of thought-would after all be quite incomplete were it limited only to the elite, even if the elite were revolutionaries.

In the police records from the Revolution we find traces of ordinary women: laundrywomen, shop owners, working-class women, unemployed women, and the wives of artisans or merchants. We see them struggling with everyday obstacles but also supporting and participating in the Revolution-forming a women's revolutionary movement. We hear their hopes, their fears, and their despair clamoring through the statements of interrogators, police accounts, and reports-hear them utter their loves, their disillusions, their bitterness-all while the democracy was forming. Their violence completely terrifies us at times-their violence of words, actions, and feelings in which enthusiasm and hate, vindictiveness and altruism, brush dangerously close to one another. It is the revolutionary moment that is in question-the powerful moment where mannerisms and behaviors are embittered-pushed almost to their paroxysms. The point is not to hush or hide the "ferocity" or the "angry impulses," as it was once said. Nor is it to judge, but rather, to try to understand them without losing sight of the stakes that motivated these women to act. 
Tricoteuses, or "knitters," they would be called, because they knitted while they followed the assembly debates. An appellation seldom used during the Revolution but often used by their adversaries after the fall of Robespierre's party-and even surpassed by another term: "the furies of the guillotine"-this word survived as a way to designate the popular militants. But how did such a docile word, a word so inoffensive and so feminine, become charged with such a repulsive ferocity?

A woman who knits conjures images of warmth, rest, tenderness, and love; in the calm of the living room she works for others. The tricoteuse, however, evokes feelings of violence, hate, death, and blood; before the eyes of everybody and in the public tribunes, she ignites. The antinomy between these two associations assured the success of this word, which evoked the image of a feminine being dominated by anguish but harboring contradictory elements, allying the most delicate tenderness with the most extreme violence. Tricoteuse also evokes another stereotype of the woman who disguises herself - a dangerous woman beneath her domestic appearance. The word that is used to designate the activist, sans-culotte, which means "without pants" or "who does not wear pants," alludes to her dress, her appearance. Her clothing designates her social and political affiliations; her fetish, the needle, is really a weapon. As soon as you pass to her other sense, however, everything smudges, everything darkensthe activity indicated by the word tricoteuse, the activity of a peaceful mother of a family, is positive. Upon leaving the foyer to pass into the public scene, displaced, tricoteuse develops a negative meaning. And in the imagination needles are always symbolic of this sort of disloyalty; they can become dangerous; weapons without names; tools for labor tinged with bloody tips.

It is all just a question of deviance in the end. In transforming an image of warmth into an image of death, in characterizing a symbol and its opposite at the same time, tricoteuse has the advantage over furie de guillotine of being not only able to describe a political code but also daring to cross the thresholds between the private and public domains. The female political activist is described by a word that, in evoking once again the private sphere, communicates the awkwardness of her presence in the public arena. Tender, and thus feminine, women can only be that way at home; upon clearing the doorsteps of their houses they become ferocious. Although they have left the private sphere, there is nevertheless no place for them in public because they are still branded with their domestic roles-they penetrate only into an "elsewhere" where nothing is defined, or which the imagination and fancy distort. 
At the end of the eighteenth century, women were conceptualized according to their roles as mothers and spouses; their existence was only conceived under the domestic roof. They were thus immediately placed outside of the public and hence outside of the city. ${ }^{3}$ In his Encyclopedia, Diderot, although we can't really accuse him of misogyny, considers the word citoyen (citizen)-which is defined according to the possession of political rights-to be a masculine noun and explains: "One only attributes this title to women, young children, or to servants as one would to the members of a family of a citizen in the strict sense of the word; they aren't really citizens." Other dictionaries that treat citoyen as a political entity also designate it a masculine word but cannot help but use at one time or another its feminine form in order to refer to the spouse. Only the dictionaries that give a more limited sense of the citizen as a simple resident of a city officially welcome the feminine citoyenne into their pages. ${ }^{4}$ Thus women, symbolic of private spheres, could not be considered as political individuals-only their spouses could grant them any sort of political existence.

The French Revolution, in declaring the Rights of Man and the Citizen, would make the latter a holder of rights, and not just the resident of a country. Would the female citizen ever find true recognition?

This book attempts to answer this question. Through the labyrinth of archives and their fruitful abundance, it measures the interval that exists between a singular image of the woman as a symbol of the private sphere and the real women of everyday life in the street, in the family, in the studio, in the tribunes, and in clubs. Here is where the knitters lived; this is where they wove and unwove their relations to the sansculottes. Here, other portraits of women during the Revolution appear, as they negotiate, confirm, reject, or superimpose upon the stereotype of the domestic being.

And this book would like to show, despite all of the missed rendezvous and relentless searches for recognition, their encounter with citizenship.

3. Lynn Hunt, "Révolution française et vie privée," in Philippe Ariès and Georges Duby, eds., Histoire de la vie privée, vol. 4, De la Révolution à la Grande Guerre (Paris: Seuil, 1987), pp. 21-51.

4. For a more precise definition, see Dominique Godineau, "Autour du mot citoyenne," Mots 16 (March 1988): 91-110. 
